\title{
Public Opinion and the Abolition or Retention of the Death Penalty Why is the United States Different?
}

\author{
Sara Sun Beale*
}

What explains the difference between the United States and the many other countries that have abolished capital punishment? Because the United States and many other nations that have abolished the death penalty are democracies, there seems to be an obvious answer: abolition or retention reflects the preferences of the electorate. According to this view, the U.S. electorate is simply more punitive, and the question becomes explaining the difference in national attitudes. There is some truth to this explanation. As I have argued elsewhere, the U.S. public generally does favor punitive criminal justice policies. ${ }^{1}$ But that cannot be the whole story. Other nations have abolished capital punishment despite widespread public support - in many cases, support of more than 70 percent of the public at the time of abolition. In the United States, however, after the Supreme Court imposed a de facto moratorium on capital punishment in the early 1970s, strong public support led to its reintroduction in two-thirds of the states.

This paper explores the relationship between public opinion and the abolition or retention of the death penalty, comparing the U.S. experience to that of other nations (with a particular focus on Germany, France, the United Kingdom, and Canada). Although the experience of each country includes distinctive elements, several common themes emerge. In each country, political elites led the abolition movement. The structure of the electoral process and the parliamentary party system, moreover, allowed legislators and other public officials a degree of insulation from popular opinion. The elites differed from their electorates in education, experience, and knowledge of the issue. Because of these differences, support for capital punishment was much lower among these elites than among the general public. In abolishing capital punishment, the elites acted in accordance with their own views, rather than those of the median voter or the general public. Some scholars have characterized this type of political behavior as the "elite leadership hypothesis." Additionally, international agreements and norms played a significant role in Europe, making abolition difficult to reverse once enacted and helping to persuade other nations to abolish capital punishment despite the existence of popular support. Finally, abolition (whether de jure or de facto) has had a tendency over time to reduce public support for capital punishment, thus diminishing popular pressure to reverse course.

\footnotetext{
* Charles L.B. Lowndes Professor, Duke Law School, Durham, North Carolina, USA. This paper was presented at the International Society for Reform of Criminal Law's conference in Vancouver, British Columbia, June 23, 2014. The author would like to thank Hunter Bruton '16 for his assistance in the research and writing of this paper.

${ }^{1}$ See, e.g., Sara Sun Beale, The News Media's Influence on Criminal Justice Policy: How Market-driven News Promotes Punitiveness, 48 WM. \& MARY L. REV. 397 (2006)(hereinafter Market-Driven News); and Sara Sun Beale, What's Law Got to Do With It: The Political, Social, Psychological, and other Non-Legal Factors Influencing the Development of (Federal) Criminal Law, 1 BuFfALO CRIM. L. REV. 23 (1997).
} 
In contrast, the U.S. system has what one observer has called "hyper-democracy,"2 which greatly reduces the likelihood that political elites will lead a movement toward the abolition of capital punishment. Various features of the U.S. electoral process subject legislators and other elected officials to significantly more political pressure than their international counterparts, especially on hot-button issues like capital punishment. As a result, U.S. political elites have much stronger incentives to act in accordance with public opinion. The federal structure has also made abolition more difficult. The states have primary authority over the criminal law. Although eighteen states have abolished the death penalty, support for the death penalty remains very high in other states (especially in the South and Southwest). Additionally, the American public and elected elites place little weight on international opinion, and the United States has not joined international agreements that would require abolition. Paradoxically, however, the Supreme Court has relied upon public opinion to overrule the results of the democratic process, restricting (though not eliminating) capital punishment under the Eighth Amendment's Cruel and Unusual Punishments Clause.

In light of the Supreme Court's unwillingness to abolish capital punishment, opponents of capital punishment have adopted a two-pronged strategy. First, they are bringing constitutional challenges to the methods of execution. Second, they are focusing their political energy on state legislatures, where their arguments for abolishing the death penalty include both the risk of wrongful convictions and the high cost of capital punishment relative to life imprisonment.

After a general comparison of key differences between the electoral structure of the United States and abolitionist countries, this paper turns to brief case studies of the abolition experience in Germany, France, the United Kingdom, and Canada. The final section then contrasts these case studies with the U.S. experience.

\section{Institutional Structures and Political Culture}

\section{A. The U.S. System: Hard Wired to Be Responsive to Public Opinion}

In the United States a variety of institutional structures and closely related cultural features make legislators and other political leaders highly responsive to public opinion and also less likely to act on distinctive elite views. Short electoral cycles, term limits, and the primary election system mean that even the most senior elected officials are continuously considering the electoral implications of their actions, raising campaign contributions, and often deliberately cultivating an anti-elite image.

At both the state and federal level, terms of service and electoral cycles are generally short. In general, state laws provide for two-year terms for members in the lower state house,

\footnotetext{
${ }^{2}$ Anthony King, Running ScARed: Why Politicians SPEnd More Time CAMPAign Than Governing 44-46 (1997).
}

2 - Draft June 20, 2014 
two- or four-year terms for the upper chamber, ${ }^{3}$ and four-year terms for the governor. In addition, fifteen states limit the number of years an elected member may serve in the state legislature, ${ }^{4}$ and many states also have term limits for the governor. At the federal level, members of the House of Representatives serve two-year terms, the President serves a four-year term, and Senators serve six-year terms.

Primary elections are used to select the Republican and Democratic candidate for each electoral position, and even incumbents must run in the primary election. In state and federal elections, even senior party leaders may lose their positions in the primary or general election if they are perceived as out of touch with the voters in their district. For example, in June 2014, the second-highest-ranking Republican in the House of Representatives, Majority Leader Eric Cantor, was defeated in the primary election by a political newcomer who ran with the endorsement of the Tea Party. The winning candidate criticized Cantor for being too willing to compromise on immigration and support some form of amnesty for undocumented immigrants. A conservative commentator said "that the primary results were 'an absolute repudiation of establishment politics' and that Republican leaders should take note." Indeed, the media attributed Cantor's loss, in part, to the close associations he maintained with political elites in Washington at the expense of serving his own constituents. ${ }^{6}$ Commentators predicted that Cantor's defeat would push the Republican House leadership further to the right and embolden the chamber's most stubborn conservatives, who had long chafed at what they saw as "an accommodating leadership."7 Similar defeats have occurred in general elections: in 1994, House Speaker Thomas Foley, the leader of the House Democrats, lost to a little-known Republican during a general election that delivered control of Congress to the Republicans. ${ }^{8}$

The political culture in the United States generally rewards candidates "who are conspicuously anti-elitist in their rhetoric and folksy in their self-presentation." 9 For example, some voters supported George W. Bush because "he is a 'guy's guy.'... because he seems like the kind of guy you could 'sit down and have a beer with.' You know, kick back with a couple of ice cold Budweisers, talk about deer hunting, and then go out back and cut down some trees

\footnotetext{
${ }^{3}$ States with four-year terms for members of the upper house (usually called the senate) include California, Florida, Ohio, Michigan, and Virginia. States with two-year terms include Arizona, Massachusetts, New York, and North Carolina. Illinois and Minnesota have more complex schemes in which members alternate between serving twoand four- year terms.

${ }^{4}$ NATIONAL COUNCIL OF STATE LegislatURES, TERm Limited STATES, http://www.ncsl.org/research/about-statelegislatures/chart-of-term-limits-states.aspx (last visited, June 18, 2014).

${ }_{5}^{5}$ Jonathan Martin, Eric Cantor Defeated by David Brat, Tea Party Challenger, in G.O.P. Primary Upset, N.Y. TIMES, June 10, 2014 (quoting Laura Ingraham on Fox News).

${ }^{6}$ Ashley Parker \& Jonathan Martin, Population Shifts Turning All Politics National, N.Y. TiMEs, June 16, 2014, at A1.

7 Jonathan Weisman, Cantor Resigns Leadership Post in Effort to Smooth House Transition, N.Y. TIMES, June 11, 2014.

${ }^{8}$ Martin, supra note 5 .

${ }^{9}$ Carol S. Steiker, Capital Punishment and American Exceptionalism, 81 OR. L. REV. 97, 115 (2002).
}

3 - Draft June 20, 2014 
together." ${ }^{10}$ Seeking to capitalize on this phenomenon, candidates frequently dress in jeans or other casual clothing at public appearances and in photographs for their campaign literature.

Carol Steiker argues that this institutional culture creates a strong tendency to defer to public opinion rather than adopt a distinctly elite position:

...Americans have always tended toward a conception of government as appropriately "provincial, amateur, authentic, spontaneous, candid, homogeneous, traditional, popular, organic, rights-oriented, religious, voluntary, participatory, and rotational" as opposed to "cosmopolitan, expert, authoritative, efficient, confidential, articulated in its parts, progressive, elite, mechanical, duties-oriented, secular, regulatory, and delegative." This political culture creates a strong tendency to defer to clear majority sentiment, not merely as a matter of political expediency, but also as a reflection of the role-conception of elected officials. ${ }^{11}$

\section{B. The Abolitionist States: Insulating Public Officials From Public Opinion}

From a U.S. perspective, the idea that elected officials would buck public opinion on a major issue like capital punishment is surprising, but that is exactly what occurred in virtually every country that abolished the death penalty. Although each case study described below includes unique features or historical events, common elements of the electoral systems promoted a critical degree of independence from public opinion. Institutional and cultural factors also fostered the development of politicians who understood their role to be using their expertise to make decisions in the public interest, rather than simply representing the views of the electorate.

Once each country had abolished capital punishment, two other factors then made its reintroduction less likely. First, several international treaties banned capital punishment, making it much more difficult for signatory countries to change course while at the same time giving politicians an excuse for maintaining the status quo. Second, abolition itself seemed to change public opinion over time, reducing support for capital punishment.

In general, capital punishment fell under the jurisdiction of the national legislature in the countries studied, ${ }^{12}$ and their electoral systems shielded individual legislators somewhat from reprisals from the electorate for their votes on an issue such as capital punishment. In these electoral systems, incumbent members typically held terms of office significantly longer than their U.S. counterparts. Moreover, primary elections generally were not used in Europe or Canada, and voters selected candidates in the general election on the basis of their party affiliation, rather than voting for individuals. Most incumbents did not anticipate facing a reelection campaign within two years or less, including a primary in which they may be

\footnotetext{
${ }^{10}$ Thomas Negorski, Want a President You Can Have a Beer With?, ABC News, Sept. 23, 2008, http://abcnews.go.com/blogs/headlines/2008/09/want-a-presiden/ (last visited June 16, 2014).

${ }^{11}$ Steiker, supra note 9, at 116 (quoting GARY WILLS, A NECESSARY EVIL: A HISTORY OF AMERICAN DISTRUST OF GOVERNMENT 17-18 (1999).

12 Andrew Hammel, Ending The DeAth PenAlty in Europe: The European EXPERIENCE In GLOBAL PERSPECTIVE 169 (2010).
} 
challenged within their own party. Moreover, the fact that political parties chose their own candidates for election rather than "throwing the question open to popular intervention" reduced the chance that candidates would have to take populist stances on hotly contested issues like capital punishment. ${ }^{13}$ It thus seems likely that, when deciding whether to abolish capital punishment, legislators were less concerned about reelection than their U.S. counterparts.

These institutional features also promoted "a political culture in which political leaders are viewed and view themselves as educated elites who have a duty to make decisions in light of their expertise and thus, more often than in the United States, to lead the public rather than follow it." ${ }^{\prime 4}$ This is consistent with a trustee model of representation (associated with Edmund Burke), rather than a delegate model. ${ }^{15}$ Given these institutional features, elites opposed to capital punishment were more likely than their U.S. counterparts to openly support abolition, and elite opinion became increasingly opposed to capital punishment. Politicians and other influential elites accorded significant weight to research demonstrating that capital punishment had no significant deterrent effect and that innocent persons had likely been executed.

Because policy concerning capital punishment was made at a national level, international norms were more influential. ${ }^{16}$ And once capital punishment had been abolished, international treaties made the reintroduction of capital punishment less likely. The Council of Europe played a leading role in the battle for abolition, and all of the Council's forty-seven member states have now either abolished capital punishment or at least instituted a moratorium on executions. In 1983, the Council adopted a protocol to the European Convention on Human Rights banning the death penalty except in time of war, and in 2002, it abolished capital punishment in all circumstances, even for acts committed in times of war. ${ }^{17}$ Abolition of the death penalty is now a precondition for entry into the European Union. ${ }^{18}$ After abolition, these international treaties serve both a legal and a political function. As a legal matter, they remove the issue from the normal legislative agenda. As a political matter, politicians who want to maintain abolition and satisfy the public can explain that international obligations effectively tie their hands. ${ }^{19}$ Finally, these treaties provided an impetus for change in other countries (such as Turkey) that had not already abolished the death penalty but wished to gain membership in the EU.

Finally, after a sufficient period, abolition has tended to delegitimize the death penalty and reduce public support, thus diminishing the pressure for reintroduction. ${ }^{20}$ One study found that, controlling for all other variables, citizens residing in a country with the death penalty are almost three times as likely to support the death penalty as citizens living in a country without

\footnotetext{
${ }^{13}$ Steiker, supra note 9 , at 114-15 (2002).

${ }^{14} I d$. at 117.

${ }^{15}$ HAMMEL, supra note 12 , at 83.

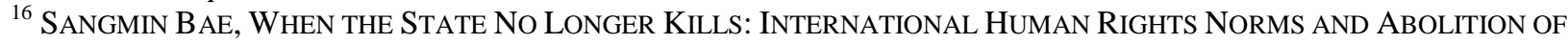
CAPITAL PUNISHMENT, 120 (2007).

${ }^{17}$ Renate Wohlwend, The Efforts of the Parliamentary Assembly of the Council of Europe, in DEATH PENALTY ABOLITION IN EUROPE, 55 (1999).

${ }^{18}$ HAMMEL, supra note 12 , at $177-78$.

${ }^{19}$ Id. at $114-15$.

${ }^{20}$ Steven Stack, Public Opinion on the Death Penalty: Analysis of Individual-Level Data From 17 Nations, 14 INT'L CRIM. Just. REV. 69, 78 (2004).
} 
the death penalty. ${ }^{21}$ For instance, in France, support for the death penalty fell by 20 percent over the course of approximately twenty-five years. ${ }^{22}$ Similarly, more than fifty years after abolition of the death penalty in Germany, public support had fallen by more than 50 percent. $^{23}$ This change in behavior did not happen immediately, and it was likely due in part to the attitudes of younger generations who grew up without capital punishment. ${ }^{24}$

\section{Case Studies}

This section provides brief case studies of abolition in Germany, the United Kingdom, Canada, and France, which are discussed in chronological order.

\section{A. Germany $y^{25}$}

The German politicians and other elites who brought about the abolition of capital punishment in 1949 were influenced by two major factors: scholarship demonstrating that capital punishment did not deter crime and had a brutalizing effect on the public, and Germany's experience with state-sponsored violence during World War II. ${ }^{26}$ Abolition was accomplished by adding Article 102 to the "Basic Law" (which functions as Germany's constitution). At the time of abolition, 77 percent of the public supported capital punishment, ${ }^{27}$ but German political elites viewed the public as inexpert and uninterested in important scholarship demonstrating its lack of deterrence. ${ }^{28}$ Some country-specific factors also played an important role. The recent Nazi regime's abuses of the death penalty served as a cautionary tale of the evils of statesponsored violence. $^{29}$

Germany's institutional structure and norms created the necessary environment for change by providing a degree of insulation from public opinion. The structure of Germany's representative democracy buffered the political elites from constantly changing political opinion, and these elites understood their role in Burkean terms. ${ }^{30}$ One politician went so far as to characterize the essence of democracy as a "parliamentary aristocracy governed by well-trained elites.",31

${ }^{21}$ Id. at 86.

${ }^{22}$ Roger Hood \& Carolyn Hoyle, The Death Penalty: A Worldwide Perspective 376 (2008).

${ }^{23} \mathrm{Id}$.

${ }^{24} I d$.

${ }^{25}$ This discussion is limited to developments in West Germany, which formed the basis for the German legal structure upon reunification. East Germany officially abolished capital punishment in 1987. HAMMEL, supra note 12 , at 82 .

${ }^{26} \mathrm{Id}$. at $66-68$.

${ }^{27}$ Id. at 66.

${ }^{28}$ Id. at 84.

${ }^{29}$ Id. at 83. Influential Nazi sympathizers were early supporters of abolition for reasons of their own. Hans Christoph Seebohm, a "wealthy industrialist who had collaborated with the National Socialist regime" first proposed the constitutional clause banning capital punishment $I d$. at 64 . Seebohm was motivated by an ultimately futile effort to halt executions of Nazi war criminals by Allied occupying powers. Scholars do not agree on the importance of Seebohm's proposal.

${ }^{30} \mathrm{Id}$. at 83 .

${ }^{31}$ Id. at 68 .

6 - Draft June 20, 2014 
Although German politicians might not use this language today, ${ }^{32}$ it conveys an important insight into the structure of European politics.

The German electoral process insulates members of the German federal parliament, the Bundestag, from the electorate. Although some members of the Bundestag are directly elected, others are selected by their political party, which places them on its list of candidates. ${ }^{33}$ The majority party or governing coalition then selects the prime minister. This institutional structure somewhat shields German representatives from popular opinion and puts primacy on a Burkean trusteeship model of government where a politician's action is not dictated simply by the preference of a majority of his constituency. ${ }^{34}$ This structure, and the norms that underlie it, allowed the key German political actors to act outside of public opinion and in accordance with their own understanding of the negative effects of capital punishment.

Expert opinion was critical not only to the abolition of capital punishment 1949, but also in preventing reinstatement. The German Criminal Law Commission "played an important role in deferring and defusing the contentious issue of capital punishment." 35 In the late 1950s, reinstatement of capital punishment gained political support. ${ }^{36}$ At that time, individual lawmakers in Germany normally did not submit important legislation unless it had been worked out in relevant government ministries and was subsequently voted on by the Federal Cabinet. ${ }^{37}$ In matters of criminal law, the Federal Cabinet largely deferred to the Commission, which was composed of academics, judges, prosecutors, and other legal bureaucrats, ${ }^{38}$ who consistently opposed the death penalty. ${ }^{39}$ This process allowed politicians to avoid reprisal from the public, both before and after the Commission made decisions. Politicians could point to the Commission's ongoing deliberations as "an excuse to defer considering the question themselves," and after its vote "they could avoid taking personal responsibility for any position on the death penalty by pointing to the Commission's careful consideration of the issue and the rejection of capital punishment." 40 Additionally, abolition's constitutional status meant that even strong majorities fell short of the required two-thirds vote to amend the Basic Law. ${ }^{41}$

Finally, Germany signed onto several international treaties codifying abolition, thus further adding to the institutional barriers preventing the reintroduction of capital punishment. Germany is a party to Protocols 6 and 13 of the Council of Europe, which ban capital

\footnotetext{
${ }^{32}$ Id. at 70 .

${ }^{33} I d$. at 69.

${ }^{34}$ Id. at $69-70$.

${ }^{35} \mathrm{Id}$. at 72. The Commission was an advisory body formed by the federal government, not a parliamentary committee.

${ }^{36} I d$.

${ }^{37} \mathrm{Id}$.

${ }^{38}$ Id. at 73 .

${ }^{39} \mathrm{Id}$. at 72 .

${ }^{40}$ Id.

${ }^{41}$ Id. at 66.
} 
punishment. $^{42}$ Further complicating any effort to reintroduce capital punishment, abolition of the death penalty is also a precondition for entry to or membership in the European Union. ${ }^{43}$

\section{B. United Kingdom}

In the United Kingdom, as in Germany, opposition to capital punishment became increasingly prevalent among elites, and elite views carried the day in Parliament despite strong public support for retention. Elites were influenced by research demonstrating a lack of any deterrent effect, ${ }^{44}$ and there were recent cases in which it appeared that innocent men had been executed for crimes they did not commit. ${ }^{45}$ When the Labour government took office in 1964, there was widespread support for abolition among members of the House of Commons, including Conservatives, ${ }^{46}$ and the new government gave its support-first tacit and later explicit - to abolition legislation sponsored by a backbencher who was not part of party leadership. Despite public opinion polls showing that 60 to 70 percent of the electorate favored retention, Parliament imposed a five-year ban on capital punishment. ${ }^{47}$ Four years later, Parliament abolished capital punishment for ordinary crimes. ${ }^{48}$ The Conservative party chose not to make an issue of Labour policies that might have engaged "the more extreme prejudices of the electorate," 49 and leaders of the three major parties voted individually for the bill making abolition permanent.

The government did not publicly support the initial steps toward abolition, though it provided increasingly strong support. The legislation that suspended the death penalty for five years arose from a private member's bill, ${ }^{50}$ and it was passed by a free vote. ${ }^{51}$ The issuing member of the bill was Sydney Silverman, a backbencher at the time, who was a former Labour party leader and longtime opponent of the death penalty. ${ }^{52}$

\footnotetext{
${ }^{42}$ COUNCIL OF EUROPE, http://conventions.coe.int/Treaty/Commun/ChercheSig.asp?NT=187\&CM=\&DF=\&CL=ENG (last visited May 27, 2014) (Protocol No. 6 and 13).

${ }^{43}$ HAMMEL, supra note 12, at 177-78; EUROPEAN UNION, http://eeas.europa.eu/human_rights/adp/index_en.htm, (last visited May 27, 2014).

${ }^{44}$ But see R.J. Buxton, Criminal Law Reform: England, 21 AM. J. COMP. L. 230, 240 (1973) (describing some studies in the late 1960s that suggested that capital punishment might have a deterrent effect in England).

${ }^{45} I d$.

${ }^{46}$ A noticeable increase in support for abolition occurred among the Conservative members of Parliament between the time similar bills were defeated in the 1950s and the period roughly ten years later when the abolition legislation was passed.

47 The "Murder Act" suspended the death penalty in England, Wales, and Scotland for a period of five years after its passage by free vote. HAMMEL, supra note 12, at 110.

${ }^{48}$ The death penalty was retained for some military offenses and crimes against the state (e.g. treason) until 1998, but imposition of capital punishment has not taken place since 1964. BRIAN P. BLOCK \& JOHN HOSTETTLER,

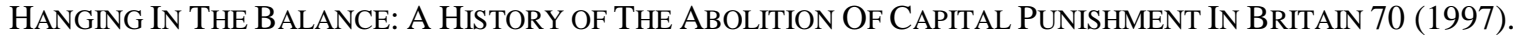

${ }^{49}$ Buxton, supra note 44 , at 240

${ }^{50}$ Under the "private member's" bill system some days each year were set aside for bills proposed by individual members (rather than those proposed by the government). Buxton supra note 44 at 232 .

${ }^{51}$ A free vote allows members allowed to vote their conscience, instead of by party line.

${ }^{52}$ HAMMEL, supra note 12 , at $87,96-109$.
}

8 - Draft June 20, 2014 
Reliance on the private-member bill and a free vote allowed the Labour party to claim that the abolition of the death penalty was not part of its agenda. The bill originated from a backbencher and was voted on individually by members of Parliament. ${ }^{53}$ Behind the scenes, however, the government provided significant support for the moratorium bill. It made legislative time available and encouraged the Queen to express support for the bill. ${ }^{54}$ When she later mentioned the bill in a speech, it was the first time she had referred to a private member's bill in her public comments. ${ }^{55}$

In 1969, the Labour party leadership decided to schedule the final vote on abolition a year earlier than initially planned to reduce its proximity to the next general election. ${ }^{56}$ Although this was again a free vote, party leaders led by example, with all three major party leaders in the House of Commons voting for abolition. ${ }^{57}$ This leadership proved invaluable, as it heavily influenced the House of Lords to pass the measure, and led to the permanent abolition of the death penalty in $1969 .{ }^{58}$

The United Kingdom's commitment to international treaties has erected significant obstacles to any attempts to reintroduce capital punishment. In 2002, the United Kingdom signed Protocol No. 13 to the European Convention on Human Rights and Fundamental Freedoms, which prohibits capital punishment in all circumstances. ${ }^{59}$ Although public opinion has continually been in favor of the death penalty, multiple attempts to reintroduce it have failed. $^{60}$

The United Kingdom's abolition of the death penalty differs from the German story in two important ways. First, abolition in the United Kingdom occurred in stages, with a moratorium preceding final abolition, whereas the Germans abolished capital punishment in one fell swoop. Second, the United Kingdom's political elite made deft use of parliamentary procedures that allowed them to distance themselves from the legislation. But, in both countries, the story is still essentially one of political elites making decisions contrary to public opinion. These strategies were seen as "elite measures, which were crafted and implemented in response to advances in criminology and psychology, rather than [in reaction] to pressure from public opinion." $" 61$

\section{Canada}

Canada's path to abolition included many of the same elements as those in other case histories: strong support from committed elites whose views differed substantially from those of

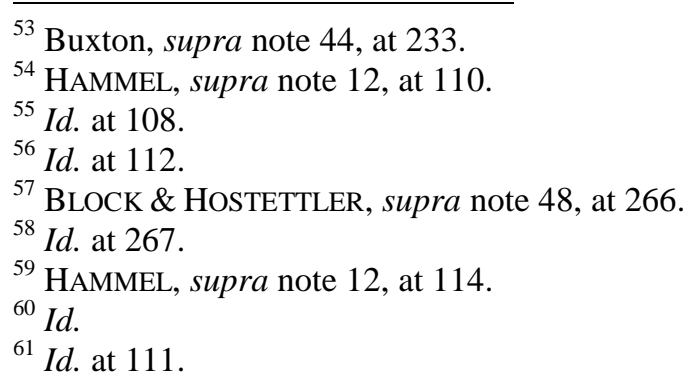


the public, multiple moratoriums before final abolition, research finding that the moratoria did not increase crime, and passage of the critical legislation by free votes. The Canadian Executive kickstarted the process by using the clemency power to create a de facto moratorium and unlike in Germany or the United Kingdom, the parliamentary debate was especially prolonged and impassioned, focusing on moral objections to the state taking life. Although subsequent efforts to reinstate capital punishment have come close to success in the past, treaty obligations now commit Canada to abolition.

Executive action created a de facto moratorium from 1963-67. When the Liberal Party came to power, the federal cabinet exercised the crown's clemency power to commute every capital case to life imprisonment. ${ }^{62}$ During this informal moratorium, support for the death penalty in Parliament declined. ${ }^{63}$ After four years under the de facto moratorium, the Canadian Solicitor General published a report concluding that suspension of the death penalty had not increased the homicide rate. ${ }^{64}$

The federal government then proposed legislation to impose a formal moratorium, as well as other bills intended to make Canada's sentencing laws more humane. Because the minority government recognized that capital punishment was still considered legitimate by much of the country and that Parliament itself was deeply divided, it proposed a compromise: an experimental five-year moratorium excluding those convicted of mudering police officers and other law enforcement officials. ${ }^{65}$ Under a new prime minister, Pierre Elliott Trudeau, this moratorium was extended. ${ }^{66}$

In 1976, the staunchly abolitionist Solicitor General introduced Bill C-84 to abolish the death penalty. ${ }^{67}$ Despite the fact that over 70 percent of the population supported capital punishment, ${ }^{68}$ Prime Minister Pierre Elliott Trudeau gave the bill his "impassioned" support. ${ }^{69}$ He characterized capital punishment as "the emotive response of a 'socially bankrupt' society," not fit for a modern, rational state. ${ }^{70}$ Parliament remained deeply divided, and the debate was highly charged and prolonged: 120 members spoke over a period of several months. ${ }^{71}$ Opponents questioned the legitimacy of the bill in light of the strong popular support for the death penalty, raised the specter of terrorism and increases in violent crime, and tried to weaken the bill with amendments. The bill's fate was uncertain.

\footnotetext{
${ }^{62}$ Andrew S. Thompson, Uneasy Abolitionists: Canada, the Death Penalty, and the Importance of International Norms 1962-2005, 42 J. OF CANADIAN STUDIES 172, 174 (2008).

${ }^{63} I d$.

${ }^{64}$ Marie Gottschalk, The Long Shadow of the Death Penalty, in Is THE DEATH PENALTy DyING? EUROPEAN AND AMERICAN PERSPECTIVES 292, 314 (Austin Sarat \& Jürgen Martschukat eds., 2011).

${ }^{65}$ Thompson, supra note 62 , at 174-75.

${ }^{66} I d$. at 175 .

${ }^{67} \mathrm{Id}$.

${ }^{68} I d$. at 176.

${ }^{69} \mathrm{Id}$. at 175 .

${ }^{70} \mathrm{Id}$.

${ }^{71} I d$.
} 
The Prime Minister and Solicitor General opted for a free vote, because it would insulate the government if the vote failed. The bill passed by a slim margin of 130 to 124, abolishing the death penalty for all ordinary offenses. ${ }^{72}$

Although Parliament came close to reinstating the death penalty in 1987, Canada remains abolitionist. $^{73}$ In 2005, the Canadian government signed and ratified the Second Optional Protocol to the International Covenant on Civil and Political Rights (aimed at international abolition of the death penalty), which now prevents Canada from reinstating the death penalty. ${ }^{74}$

\section{France}

France's path to abolition was similar to that of Canada's: the executive was the moving force in revising the penal code and abolishing capital punishment in $1981 .^{75}$ Even though public opinion favored the death penalty, François Mitterand announced during his campaign for President that he would abolish capital punishment if elected. ${ }^{76}$ Once Mitterand and his leftist parties took office, the new Justice Minister, Robert Badinter, expedited review of the abolition law through parliament. The French Parliament then abolished the death penalty by a vote de conscience. ${ }^{77}$ Strong executive leadership, influenced by French academics and law reform committees, ${ }^{78}$ provided the catalyst that led to abolition. It is worthy of note, however, that the vote de conscience meant that abolition reflected the sentiments of the individual members of parliament rather than their party.

International treaties and a constitutional amendment subsequently cemented France's stance as an abolitionist country. Because the French Constitution provides that treaties prevail over acts of parliament, ${ }^{79}$ after France signed and ratified Protocol 6 to the European Convention on Human Rights, it became much more difficult for French lawmakers to reintroduce capital punishment. The only way for France to bring back the death penalty would have been to repudiate the treaty, exposing it to external criticism and repercussions. ${ }^{80}$ In 2007 , France further raised the institutional barriers to the reintroduction of capital punishment by modifying its constitution to prohibit the death penalty. ${ }^{81}$ Despite persistent public opposition, France has rendered its absolutionist stance irrevocable for all practical purposes.

\section{Public Opinion, Politics, the Supreme Court, and Retention in the U.S.}

\footnotetext{
${ }^{72}$ Id. at 177.

${ }^{73} \mathrm{Id}$. at 179 . Canada abolished the death penalty for military crimes in 1998.

${ }^{74}$ DEPARTMENT OF JUSTICE CANADA, http://www.justice.gc.ca/eng/abt-apd/icg-gci/ihrl-didp/tcp.html (last visited June 18, 2014).

${ }^{75}$ HAMMEL, supra note 12 , at 143.

${ }^{76} \mathrm{Id}$. at 141. A vote de conscience is a free vote.

${ }^{77}$ HAMMEL, supra note 12, at 142-143.

${ }^{78} I d$. at 140 .

${ }^{79}$ Id. at 145 .

${ }^{80}$ Id. France also signed Protocol No. 13 discussed in the United Kingdom section.

${ }^{81}$ DEATH PENALTY INFORMATION CENTER, http://www.deathpenaltyinfo.org/node/2048 (last visited May 27, 2014). 11 - Draft June 20, 2014
} 
In the U.S., the story was quite different. Following a Supreme Court decision that created a de facto moratorium in 1972, legislatures in two thirds of the states acted quickly to write new legislation reinstating the death penalty. Although U.S. public support for capital punishment had dropped to 50\% — a much lower rate than any of the case-study countries at the time of abolition — both state and federal politicians came under extreme pressure to support the death penalty. Public support for capital punishment surged, and it became a major political issue over the next four decades. Both parties embraced it.

Confronted with the surge in public support, the Supreme Court developed an Eighth Amendment jurisprudence that depends upon public opinion. The Court has employed this doctrine to limit, but not prohibit, capital punishment.

\section{A. Support for Capital Punishment Declines and the Supreme Court Imposes a De Facto Moratorium}

After World War II there was significant support in the U.S. for the abolition of the death penalty. As measured by public opinion polls, support for capital punishment declined through the 1950s and early 1960s to a low of $42 \%$ in $1966 .{ }^{82}$ Between 1964 and 1969 six states abolished capital punishment, and the number of executions fell from 15 executions in 1964, to seven in 1965, one in 1966, two in 1967, and then none from 1968 until the mid 1970s. ${ }^{83}$ By 1969, 10 states had abolished capital punishment, but it was still authorized in the remaining 40 states and in federal prosecutions. ${ }^{84}$

Opponents of the death penalty mounted a sustained effort to persuade the Supreme Court that the death penalty constituted cruel and unusual punishment in contemporary U.S. society. In 1972, they had a major victory. In Furman v. Georgia, ${ }^{85}$ a five-to-four majority set aside the death sentences in three cases from Georgia and Texas. The result was announced in a short per curiam opinion that provided no explanation of the decision. Each member of the Court wrote separately, and their opinions totaled 230 pages.

Two Justices concluded that imposing capital punishment violated the Eighth Amendment because it was incompatible with evolving conceptions of human dignity. Justice Brennan compared capital punishment to "barbaric" punishments like the rack and the thumbscrew, ${ }^{86}$ and he concluded that in contemporary society it was morally unacceptable. Justice Marshall wrote that the death penalty made no measureable contribution to legitimate legislative objectives, and that the average American citizen, if fully informed on the issue, would find it "shocking to his conscience and sense of justice." 87

\footnotetext{
${ }^{82}$ SOURCEBOOK OF CRIMINAL JUSTICE STATISTICS, Table 2.51.2013, available at http://www.albany.edu/sourcebook/pdf/t2512013.pdf (last visited June 18, 2014).

${ }_{83}^{83}$ Corinna Barrett Lain, Deciding Death, 57 Duke L.J. 1, 13 \& n. 42 (2007).

${ }^{84} I d$.

${ }^{85} 408$ U.S. 238 (1972).

${ }^{86} \mathrm{Id}$. at 272(J. Brennan concurring).

${ }^{87} \mathrm{Id}$. at 369(J. Marshall concurring).
} 
In contrast, the three other justices who made up the majority focused on the capital sentencing procedures. In trials for capital offenses, juries in most states returned a sentence recommendation at the same time they returned a guilty verdict, and the typical jury instructions provided no standards or criteria for making this decision. Moreover, juries generally heard no evidence about the defendant's character, personal background, or prior criminal history. Justice Douglas wrote that these sentencing statutes operated in a manner that was "pregnant with discrimination" against poor, black defendants. ${ }^{88}$ Of 3,895 persons executed between 1930 and $1968,2,066$ were black. ${ }^{89}$ Of the 2,306 persons executed in the Southern states during this period, $72 \%$ were black. Justice White stated that the Georgia statute provided "no meaningful basis" for distinguishing the cases where death was imposed from others in which it was not." Justice Stewart wrote that capital punishment was being "wantonly and freakishly imposed," and he compared it to being hit by lightning. ${ }^{91}$

The justices in the majority believed that invalidating the death penalty was the correct action as a matter of policy, and Justices Stewart and White based their votes on the assumption that affirming the death penalty in the case before them would only delay its inevitable abolition. ${ }^{92}$ Their actions seem to parallel the elite actions in the countries examined in the case study above.

Although there was no majority opinion in Furman, all capital punishment statutes in the United States had the same procedural flaws as the Georgia and Texas statutes. Accordingly, the Furman decision effectively invalidated every death penalty statute then in force, producing a de facto moratorium on capital punishment throughout the United States. Opponents hoped that this would be the end of capital punishment in the United States. It was not.

\section{B. The States Respond to the Supreme Court, and the Supreme Court Responds to the States}

Furman provoked a dramatic response from the state legislatures. In just four years, 35 states-including Georgia and Texas - enacted new capital sentencing statutes designed to respond to the procedural objections of Justices Douglas, White, and Stewart. In Gregg v. Georgia, a 7-to-2 majority of the Supreme Court held that Georgia's new "guided discretion" capital sentencing scheme was constitutional. ${ }^{93}$ These new procedures, the majority ruled, sufficiently addressed the concern that the death penalty would be imposed in an arbitrary and capricious manner. In a later case, the Court acknowledged that the state legislative action had been critical to its decision in Gregg:

\footnotetext{
${ }^{88} \mathrm{Id}$. at 257 (J. Douglas concurring).

${ }^{89}$ RiCHARD J. BONNIE, ET AL., CRIMINAL LAW 980 n.a (3 ${ }^{\text {rd }}$ ed. 2010).

${ }^{90}$ Id. at 313 (J. White concurring).

91408 U.S. at 309-10 (J. Stewart concurring).

${ }^{92} \mathrm{Id}$. at $415-16$ (J. Powell dissenting).

93428 U.S. 153 (1976). The Georgia statute separated the sentencing decision from the trial of guilt or innocence. At the sentencing stage, the Georgia statute channeled the jury's discretion, focusing its attention on the particularized nature of the crime and the characteristics of the individual defendant. The statute identified aggravating and mitigating factors, and it required the jury to find at least one aggravating factor and consider any mitigating factors before imposing the penalty of death.
}

13 - Draft June 20, 2014 
Thirty-five States immediately reinstituted the death penalty for at least limited kinds of crime. This public judgment as to the acceptability of capital punishment, evidenced by the immediate, post-Furman legislative reaction in a large majority of the States, heavily influenced the Court to sustain the death penalty for murder in Gregg v. Georgia. ${ }^{94}$

Gregg held that the death penalty could not be imposed if it caused unnecessary and wanton infliction of pain or if it was grossly out of proportion to the severity of the crime. Whether the death penalty was constitutionally excessive would be determined by "the evolving standards of decency that mark the progress of a maturing society," 95 rather than by an analysis of historical practice at the time the Eighth Amendment was adopted. Consistency with evolving standards of decency would be determined by two factors. First, the Court would consider the "objective evidence" of a national consensus, particularly the enactments of the nation's legislatures and actual implementation of the punishment where a legislature makes it available. This methodology implicitly countered the criticism that the Court was simply imposing its own policy preference in the guise of constitutional interpretation. ${ }^{96}$ Only after considering these objective indicators would the Court make its own subjective judgment of what cruel and unusual punishment meant under the Eighth Amendment, and would then be the final arbiter on the matter.

\section{U.S. Public Opinion Favoring Capital Punishment Skyrockets and the Political Elites Get the Message}

The U.S. experienced a steep rise in support for capital punishment beginning in the early 1970s. When the strength of the public's views became clear, the elites generally fell into line, expressing their own strong support for retention and implementation of the death penalty. Although many Democrats initially opposed the death penalty and other punitive crime policies, they generally jumped on the bandwagon when it became clear that opposition would cost them elections.

By 1976, when the Supreme Court decided Gregg, 66\% of the public supported capital punishment, and support continued to increase, peaking at 80\% in 1994 and then holding steady at roughly $70-75 \%$ until the turn of the century. ${ }^{97}$ Crime became a major political issue.

National polls identified crime as the most important problem facing the United States in every year from 1994 to 1998, and in 1999 and 2000 it was selected as the second or third most important problem. ${ }^{98}$ Although a full discussion of the "law and order" politics and the "war on

\footnotetext{
${ }^{94}$ Coker v. Georgia, 433 U.S. 584, 593-94 (1977).

95428 U.S. at 173.

${ }^{96}$ As the Court later explained in Coker v. Georgia, its Eighth Amendment judgments "should not be, or appear to be, merely the subjective views of individual Justices; judgment should be informed by objective factors to the maximum possible extent." 433 U.S. at 592.

${ }^{97}$ SOURCEBOOK OF CRIMINAL JUSTICE STATISTICS, Table 2.51.2013, available at http://www.albany.edu/sourcebook/pdf/t2512013.pdf (last visited June 18, 2014).

${ }^{98}$ Beale, Market Driven News, supra note 1 at 418.
} 14 - Draft June 20, 2014 
crime" is beyond the scope of this paper, ${ }^{99}$ commentators have identified a variety of factors that seem to have played a role. These include concern about the rising crime rates, a dramatic rise in sensational coverage of violent crime in the news media, a backlash against the gains of the civil rights movement, and opportunist Republican efforts to attract formerly Democratic voters (especially those in Southern States that had most strongly opposed national civil rights legislation associated with the Democratic party). ${ }^{100}$

In this atmosphere, harsher penalties, including the death penalty, became "an issue people cared about, an emotional issue of powerful symbolic significance," 101 and attitudes about the death penalty came to have "powerful symbolic significance, support for the death penalty representing and ideological self-definition of the person as unyielding in the war on crime, unwilling to coddle criminals, firm and courageous."

Recognizing the power of the issue, U.S. politicians emphasized their support for the death penalty. At the state level, for example, the death penalty played a prominent role in three gubernatorial races in 1990:

In California, John K. Van de Kamp ran a television advertisement with a gas chamber in the background, highlighting the number of murderers that he put or kept on death row in his roles as District Attorney and Attorney General. In Texas, Jim Mattox ran against Ann Richards in the Democratic primary with ads taking credit for thirty-two executions in his role as Attorney General. In Florida, incumbent Governor Bob Martinez ran ads boasting of the ninety-plus death warrants he had signed while in office. ${ }^{103}$

The death penalty has also been an important factor in many federal elections, including presidential elections. In a nationally televised 1988 presidential debate Democratic candidate Michael Dukakis was badly hurt when he said he would not change his opposition to the death penalty if his wife were raped and murdered. Reporters concluded that Dukakis lost the debate in that single answer, and viewers across the country reported expressed "outrage" at his response. Indeed, almost 20 years later his response is still being cited as an example of the kind

\footnotetext{
${ }^{99}$ For some influential explanations, see JONATHAN SIMON, GOVERnING THROUGH CRIME (2003); William J. Stuntz, The Pathological Politics of Crime, 100 MiCH. L. REV. 505 (2001), and MiCHELE AleXANDER, THE NEW JiM CROW IN THE AGE OF COLORBLINDNESS (2010). I have explored these issues in The News Media's Influence on Criminal Justice Policy: How Market-driven News Promotes Punitiveness, 48 WM. \& MARY L. REV. 397 (2006), and What's Law Got to Do With It: The Political, Social, Psychological, and other Non-Legal Factors Influencing the Development of (Federal) Criminal Law, 1 BUFFALO CRIM. L. REV. 23 (1997).

${ }^{100}$ The legislation laying the groundwork for the "war on crime" first began appearing in the mid-1960s, a time during which the United States experienced a growing sense of social disorder reflecting both racial and non-racial factors (including opposition to the Viet Nam war). Many elected officials opposing the civil rights movement used the language of law and order to respond to and stoke racial anxiety among whites. When blatant opposition to the civil rights movement became less socially acceptable, "crime" became a coded term that marshaled racial fears without violating newly dominant egalitarian norms.

${ }^{101}$ Samuel R. Gross \& Phoebe C. Ellsworth, Second Thoughts: American's Views on the Death Penalty at the Turn of the Century, in CAPITAL PUNISHMENT AND THE AMERICAN FUTURE (2001).

${ }^{102} \mathrm{Id}$. at

${ }^{103}$ Steiker, supra note 9, at 112 (footnotes omitted).
}

15 - Draft June 20, 2014 
of answer that can kill a political candidate's career. ${ }^{104}$ Subsequent Democratic candidates did not make the same mistake. Indeed, then Governor Bill Clinton returned to Arkansas during his 1992 presidential campaign to facilitate the execution of a mentally disabled murderer. ${ }^{105}$ In 2000, each of the initial eleven candidates for president, despite their ideological differences, declared his support for the death penalty. ${ }^{106}$ Current President Barak Obama supports capital punishment (though he notes that it should be reserved for heinous crimes). ${ }^{107}$

\section{The Supreme Court's Majoritarian Constitutional Doctrine}

One of the puzzles of the U.S. experience is how to explain the Supreme Court's actions, and the related question of how to assess them. The Court's 1972 decision in Furman was surprising for several reasons: the decision had no support in the text of the Constitution (which clearly provides for capital punishment), and the Court itself had recently turned back a challenge to state capital punishment procedures. ${ }^{108}$ In 1972 the Furman majority reached out for the issue and broke entirely new ground. But just four years later in Gregg it backed down, announcing a new Eighth Amendment doctrine that has been widely criticized as lacking a firm constitutional foundation and failing to achieve its declared purposes, while nonetheless still managing to unduly interfere with the democratic legislative process.

\section{Explaining the Court's decision}

I find persuasive the argument that the majority was acting in Furman (as elites did in other abolitionist nations) to advance its own view of good policy, but that it was completely unprepared for the strong public reaction and unwilling to stake its institutional prestige on the issue. As Corinna Barrett Lain has explained, the pressure on the Court was fierce, and its legitimacy was at stake:

In 1976, remaining true to Furman's holding would have been hazardous to the Court's institutional authority. In the wake of Furman, legislators had threatened a constitutional amendment to reinstate the death penalty, and by 1976, they were close to having the numbers to pull something like that off. Even a failed, but concerted, attempt to override the Court would have been a severe blow to its power and legitimacy. With public opinion favoring the death penalty 2 to 1 , both political parties aligning on the issue, and the solicitor general asking the Court to overrule its 1972 decision, it is hard to imagine the Justices in Gregg doing anything other than what they did--retreat. ${ }^{109}$

\footnotetext{
${ }^{104}$ Roger Simon, Questions that Kill Candidates' Careers, Politico, April 20, 2007, available at http://www.politico.com/news/stories/0407/3617.html (last visited June 18, 2014).

${ }^{105}$ J. Thomas Sullivan, Furman After Four Decades, 8 U. MASS. L. REV. 164, 179-80 (2013).

${ }^{106}$ Steiker, supra note 9 , at 112.

107 2012 PRESIDENTIAL CANDIDATES, http://2012.presidential-candidates.org/Obama/Capital-Punishment.php (last visited June 19, 2014).

${ }^{108}$ McGautha v. California, 402 U.S. 183 (1971).

${ }^{109}$ Corinna Barrett Lain, Deciding Death, 57 DuKE L.J. 1, 23 (2007).
}

16 - Draft June 20, 2014 
It is understandable, then, that the majority sought to articulate a doctrine that placed some limits on the imposition of capital punishment without provoking a constitutional or political crisis. But what of the doctrine that it developed?

\section{Critiques of the Supreme Court's doctrine}

The first criticism is that Court's doctrine is far too limited: it provides only "constitutional protection that follows, rather than frustrates, majority will, prohibiting a punishment only after most states have abandoned it on their own."110

A second criticism is that the statutory schemes endorsed by the Court do not solve the problem of arbitrary and discriminatory application of the death penalty. Statistical reviews found continuing disparities by race of the victim, with suspects charged with killing white victims far more likely to receive the death penalty than those who killed black victims. ${ }^{111}$ The Supreme Court held that a study finding such disparities in the application of Georgia's statute did not demonstrate a violation of the Eighth Amendment. ${ }^{112}$ In contrast, the American Law Institute - which had promulgated the template upon which all post-Furman statutes dependwithdrew its support in 2009, citing "intractable institutional and structural obstacles to ensuring a minimally adequate system for administering capital punishment."

Critics charge that the doctrine announced in Gregg fails on its own terms, because the Court has been unable - or unwilling - to make a truly "objective" determination of state practices and public attitudes. In many of its cases, plausible arguments could be made for different categorizations of state law that favor or undermine a finding of a national consensus, and the analysis by both the majority and dissent appears to be rather transparently result-driven, rather than objective. ${ }^{114}$ Moreover, the Court has flip-flopped, reversing recent decisions after a slim majority identified a new consensus precluding the execution of juveniles and persons who are mentally ill. ${ }^{115}$

A closely related problem is that the Court's own decisions have constrained - and in some cases precluded - the development of any new consensus on the desirability of extending the death penalty. For example, a sharply divided Court held in 2008 that the Eighth Amendment barred the state of Louisiana from imposing the death penalty for the rape of a child where the crime did not result, and was not intended to result, in the victim's death. ${ }^{116}$ The majority

\footnotetext{
${ }^{110} I d$. at 4.

${ }^{111}$ Several studies are summarized in Gary Keck, Racial Discrimination in Criminal Sentencing: a Critical Evaluation of the Evidence with Additional Evidence on the Death Penalty, 46 AM. SoC. REV. 783 (1981). In the Court held that a study finding such disparities in the application of Georgia's statute did not demonstrate a violation of the Eighth Amendment.

${ }_{112}$ McCleskly v. Kemp, 481 U.S. 279 (1987).

${ }^{113}$ Message from ALI Director Lance Leibman, available at http://www.ali.org/_news/10232009.htm (last visited June 19, 2014).

${ }_{114}^{11}$ See, e.g., Enmund v. Florida, 458 U.S. 782 (1982); Tison v. Arizona, 581 U.S. 137 (1987).

${ }^{115}$ For a description of these cases, see generally Lain, supra note 109, at 24-35.

${ }^{116}$ Kennedy v. Louisiana, 554 U.S. 407 (2008).
}

17 - Draft June 20, 2014 
emphasized that only six states permitted the imposition of the death penalty for rape of a child. More broadly, the decision appeared to signal that (absent a change in the Court's membership) death would be deemed disproportionate to any crime against an individual person in which the victim's life was not taken, though the majority also noted that it was expressing no opinion about capital punishment for crimes against the state, such as treason. ${ }^{117}$ In dissent, Justice Alito observed that the Court's prior decisions had stunted legislative consideration of the question whether the death penalty for the targeted offense of raping a young child is consistent with prevailing standards of decency, and its decision was extinguishing what might well have been the beginning of new trend. ${ }^{118}$

\section{A Few Observations and Conclusions}

The case studies confirmed that at least in the particular times of abolition in Germany, the U.K., Canada, and France, elite opinion turned against the death penalty and brought about abolition despite strong public support for retention. To some degree, these elite actors relied upon a degree of insulation from public opinion and pressure that does not exist for elected officials in the United States, and they had a conception of their role that is not widely shared by U.S. political elites.

The comparison to the experience in these countries also highlights the importance of the U.S. federal system and its allocation of authority over criminal law to the States. With a few limited exceptions, the Supreme Court has now left control of capital punishment to the democratic process at the states level.

Dramatic regional differences in attitudes and practices have emerged. By the turn of the century, national polls began to show a significant decline in support for capital punishment, and a recent poll found that only $42 \%$ favored the death penalty for murder if life without parole were available. ${ }^{119}$ Three states have abolished the death penalty since $2011{ }^{120}$ But support

${ }^{117}$ The Court stated:

Our concern here is limited to crimes against individual persons. We do not address, for example, crimes defining and punishing treason, espionage, terrorism, and drug kingpin activity, which are offenses against the State. As it relates to crimes against individuals, though, the death penalty should not be expanded to instances where the victim's life was not taken.

Id. at 437.

${ }^{118}$ He wrote:

The Coker dicta gave state legislators and others good reason to fear that any law permitting the imposition of the death penalty for this crime would meet precisely the fate that has now befallen the Louisiana statute that is currently before us, and this threat strongly discouraged state legislators - regardless of their own values and those of their constituents - from supporting the enactment of such legislation.

Id. at 448 (J. Alito dissenting).

${ }^{119}$ The most recent poll, in June of 2014 , found that $61 \%$ supported capital punishment for murder, but when given a choice between life in prison and capital punishment, $52 \%$ chose life imprisonment and only $42 \%$ favor the death penalty - the fewest in polls dating back 15 years. The result followed a botched execution by lethal injection in Oklahoma in late April. ABC/Washington Post Poll: Death Penalty, June 5, 2014, http://www.langerresearch.com/uploads/1161a4DeathPenalty.pdf (last visited, June 18, 2014). 
remains strong in some regions, and capital punishment has become a minority practice localized almost entirely in a small number of states, and within certain counties. Since the Supreme Court reinstituted the death penalty in 1976, 2,008 persons have been executed; 1,754 of those were executed in Texas, Oklahoma, and states in the South. ${ }^{121}$ Texas alone accounted for 515 of the total executions. ${ }^{122}$ One advocacy group reports that only $2 \%$ of the counties in the U.S. have been responsible for the majority of cases leading to executions, as well as the majority of the current population of death row. ${ }^{123}$

Allocating authority over the retention of the death penalty to the states means that there is no mechanism to enforce a national policy of abolition, should such a policy develop, other than through the Supreme Court's Eighth Amendment jurisprudence. Moreover, at the state and local level, international norms - which might have some traction with the national government - are generally unpersuasive.

${ }^{120}$ DeATH PENALTy INFORMATION CENTER, STATES WITH AND WithOUT THE DEATH PENALTy, available at http://www.deathpenaltyinfo.org/states-and-without-death-penalty (last visited, June 19, 2014) (listing Maryland (2013), Connecticut (2012), and Illinois (2011)).

${ }^{121}$ DeAth PENAlty Information Center, FACTS About The DeAth PenAlty at 3 (Executions By Region), available at http://www.deathpenaltyinfo.org/documents/FactSheet.pdf (last visited, June 19, 2014).

${ }^{122}$ Id. at 3 (Number of Executions By State Since 1976).

${ }^{123}$ Richard C. Dieter, The 2\% Death Penalty, How a Minority of Counties Produce Most Death Cases at Enormous Costs to All (October 2013), available at http://deathpenaltyinfo.org/documents/TwoPercentReport.pdf (last visited June 19, 2014).

19 - Draft June 20, 2014 